\title{
Greek, Tamil and Sanskrit: \\ Comparison between the Myths of Herakles (related with Iole and Deianira) and Rama in Hinduism
}

\author{
By D Pugazhendhi*
}

\begin{abstract}
The Greek Historian Arrian has said that the Indians worshipped Greek Herakles. So the myths related with Greek Herakles need to be compared with the myths of the Indian Gods. There are many myths related with Herakles. The myth related with Iole and Deianira has resemblance with the myth of Rama in Hinduism and Buddhism. The word Rama which is connected with sea is mentioned in the Hebrew Bible. This word came into existence in the ancient Tamil literature called Sanga Ilakkiam through the trade that happened among the people of Greek, Hebrew and Tamil. The myths of Rama that occurred in the Tamil Sangam literature later developed as epics in Sanskrit, Tamil and other languages. Further the myths of Rama also found place in religions such as the Hinduism and the Buddhism. The resemblance between Herakles, in connection with Iole and Deianira, and Rama are synonymous. Hence the Greek Herakles is portrayed as Rama in Hinduism and Buddhism.
\end{abstract}

Keywords: Arrian, Buddhism, Herakles, Rama, Tamil Sangam

\section{Introduction}

Herakles is portrayed in diverse forms: God and hero across the globe ${ }^{1}$. The Greek historian Arrian had mentioned that Herakles was worshipped as God in Methora of India.

\section{Methora and Herakles}

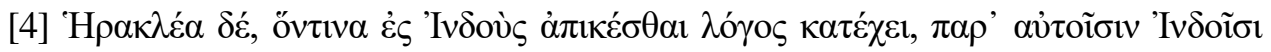
$\gamma \eta \gamma \varepsilon v \varepsilon \dot{\alpha} \alpha \lambda \dot{\varepsilon} \gamma \varepsilon \sigma \theta \alpha \mathrm{\alpha}$.

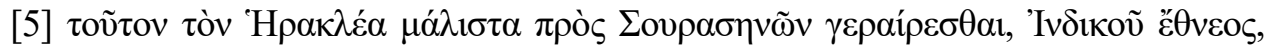

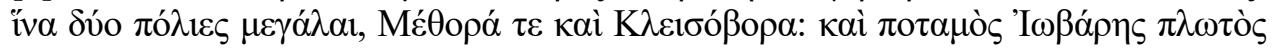

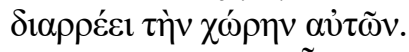

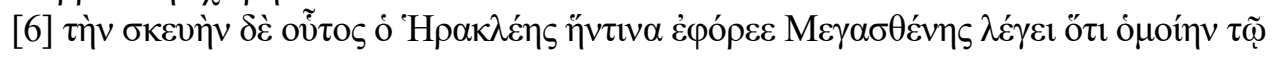

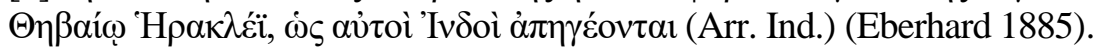

"The Hercules who penetrated so far, the Indians tell us, was a native of their country. $\mathrm{He}$ is particularly worshipped by the Suraseni, who have two great cities, Methora and Cleisoborus, and the navigable river Jobares, passes through their territories. This

\footnotetext{
*Associate Professor, Government Arts College, India.

${ }^{1}$ Herakles moreover provides a conduit for international religious exchange. Non Greeks worshipped him, often in conjunction with one of their own deities. The Lydians adopted Herakles and the Phoenicians shared his cult with Melqart (Padilla 1998, p. 3).
} 
Hercules, as Megasthenes asserts, and the Indians themselves assure us, uses the same habit with the Theban Hercules" (Arrian, Indica, Chapter viii) (Eberhard 1885).

In Tamil, Methora is Mathurai. A poet from Mathurai has spoken of a name Rama that had found a place in the ancient Tamil literature has resemblance with Herakles.

\section{Methora and Rama}

Tamil language is one of the classical languages that of Greek. It has a vast literary heritage. Connect between diverse nations and multiple lands are established in this literature. The first available literature called Sangam literature contains some poems that belonged to 1200 BC (Pugazhendhi 2020b, p. 188). In this literature one of the poets is Mathurai Tamil Koothanār Kaduvan Mallanār. He had mentioned a foreigner named Rama in his poem.

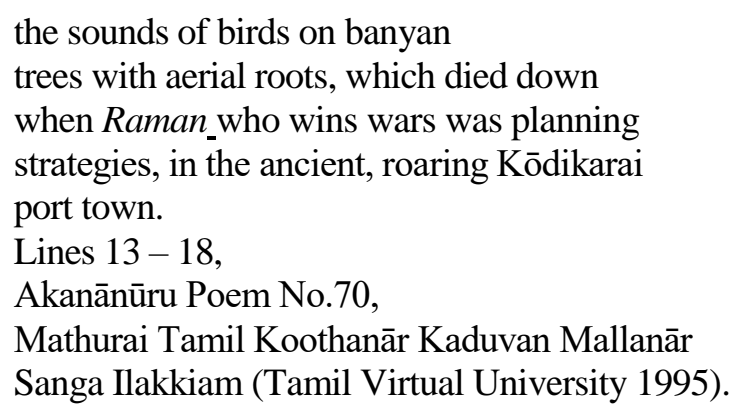

This myth has a resemblance with the myth of Heracles.

But in the case of Heracles his piety was such that the opposite happened to him. For when he had arrived at the border between Rheginê and Locris and lay down to rest after his wearying journey, they say that he was disturbed by the crickets and that he prayed to the gods that the creatures which were disturbing him might disappear; whereupon the gods granted his petition, and not only did his prayer cause the insects to disappear for the moment, but in all late times as well not a cricket has ever been seen in the land.

Diod. 4.22.5

Diodorus Siculus, Bibliotheca Historica (Bekker 1890)

Greek history, 480-431 BC

This Rama, in one of the instances, is depicted as a man with the lion head.

1042. You, the god of the tall majestic Thiruvenkațam hills, took the form of a pillar, split it open, emerged from it in the form of a man-lion and killed the Asuran Hiranyan.

Your arrows never fail to hit their targets.

10. Thiruvenkațam,

Periya Thirumozhi, 
Thirumangai Azhvar (Kausalya 2018).

The above thoughts are figuratively compared with Greek Herakles in Figure 1.

Figure 1. Greek and Methora Herakles
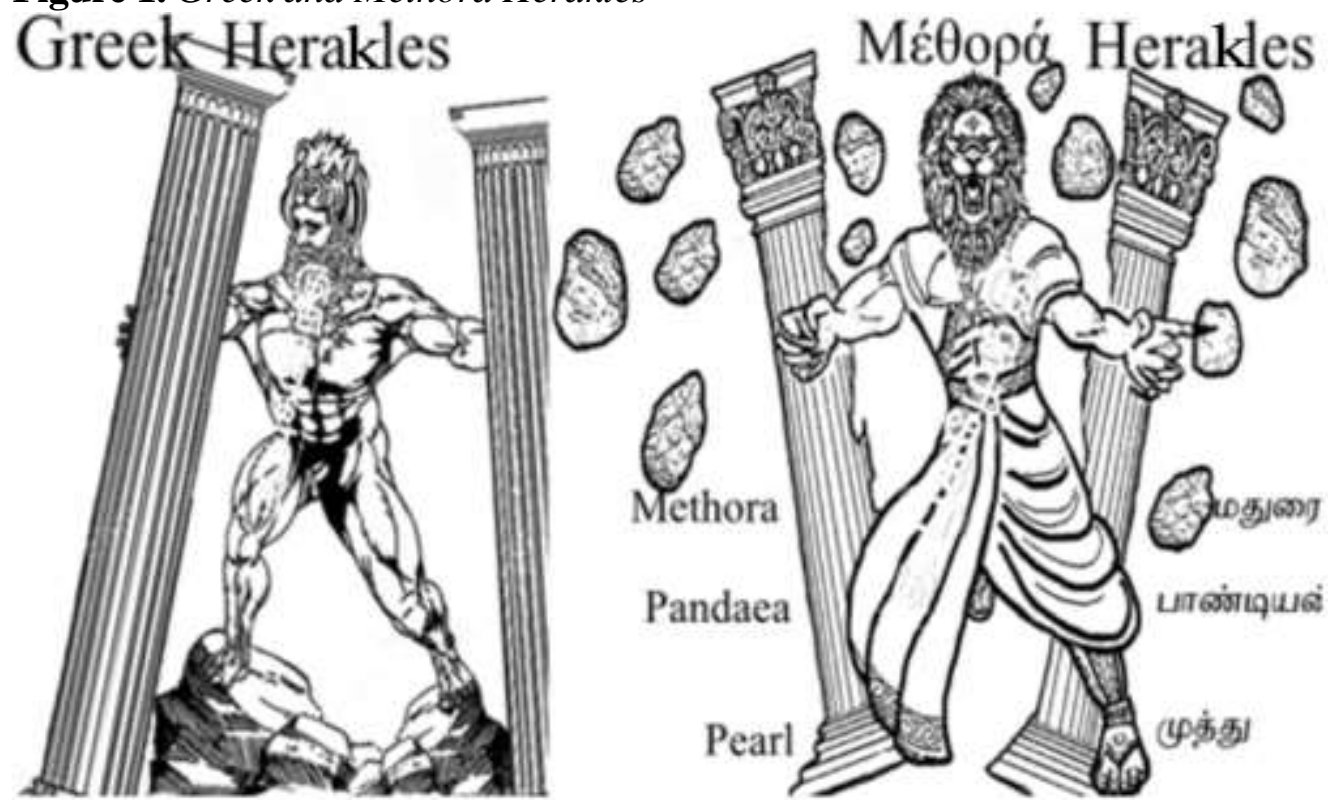

Thus, the myths related with Rama have resemblance with the myths of Herakles. So the root of the word Rama should be researched.

\section{Rama in Hebrew}

Ancient Tamilians had sea trade relation with many foreign countries (Pugazhendhi 2020a, 2020b). Because of this, several foreign words occurred in ancient Tamil language. One such word is Raman is also seen in the strong Hebrew No.7484 Ramah or Rama.

"And the sons of Cush Seba and Havilah and Sabtah and Raamah and Sabtecha and the sons of Raamah Sheba and Dedan" (Genesis 10:7, Hebrew Bible) (NASB 1981, Briggs 2006).

"The merchants of Sheba and Raamah they were thy merchants they occupied in thy fairs with chief of all spices and with all precious stones and gold" (Ezekiel 27:22, Hebrew Bible) (NASB 1981, Briggs 2006).

The word Ramah indicates height in the strong Hebrew No. 7414. This word is also has several other indications - name of the person, son of God and people involved in sea trade. In strong Greek, the same word signifies the name of a place.

Rama in Greek

The word Rhama Pajó is listed in the strong Greek No. 4471. 


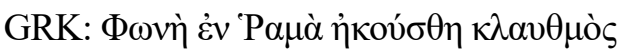

NAS: was heard in ramah, weeping (Matthew 2:18 N) (NASB 1981, Briggs 2006).

Thus, through sea trade, the Tamil literature might have borrowed the word Rama from Hebrew or Greek. The word Rama that represents a name of a person in Hebrew and Greek, seem to have undergone some changes in Tamil because of it usage as to represent a man of higher stature.

In the same way Rama was mentioned as a noble who was related with the trade of horse in the foremost Sanskrit literature called Rig Veda.

"This to Duhśsima Pṛthavāna have I sung, to Vena, Rama, to the nobles, and the King. They yoked five hundred, and their love of us was famed upon their way.

Besides, they showed us seven-and-seventy horses here" (Rig Veda ${ }^{2}$ 10.93.14.) (Griffith 1896)

\section{Rama in Hinduism and Buddhism}

The myth of Rama was then developed at the level of an epic. In Sanga Ilakkiam, Puranānūru poem number 358 was penned by Tamil poet Vānmeekiyār. This poet or some one of his lineage had made use of the myth Rama and wrote the epic Ramayana in Sanskrit (Ralph 1874$)^{3}$. It consists of nearly 24,000 verses divided into five parts (kāṇụs). Another poet Kamban also authored an epic in Tamil, using the same myth. This book has 6 chapters (KAndam), each KAndam is divided into a number of sections; there are 118 sections which collectively contain approximately 12,000 poems. This expanded work of art gave rise to the elaboration of the myth of Rama. This expanded version is not seen in the myth of Herakles and hence the details are not found. The Buddhist literature also has the myth of Rama in song no. 461. In Dasharatha Jataka it is mentioned that he was the former birth of Buddha (Rouse 1901).

\section{Myth of the Herakles related with Iole and Deianira}

There are many myths related with Herakles in Greek. The myth of Herakles related with Iole and Deianira has resemblance ${ }^{4}$ with the myth of Rama. Iole and Deianira were two women. The myths of Iole and Deianira related with Herakles,

\footnotetext{
${ }^{2}$ Mentioned about Tamilians

tamīḷata prathamaṃ yajñasādhaṃ viśa ārīrāhutaṃ ṛñasānam |

ūrjah putram bharatam sṭpradānum devā ...(Rig Veda 1.96.3)

Praise him, ye Tamil तमीळ folk, as chief performer of sacrifice adored and ever toiling,

Well-tended, Son of Strength, the Constant Giver. The Gods possessed the wealth bestowing Agni. (Griffith 1896)

${ }^{3}$ Ramayana written by Valmiki in the Sanskrit mentioning the historical kings who were mentioned in the Tamil Sangam literatures.
}

\section{Colān(चोलान) pāṇdyān(पाण्ड्यान) sakeralān(सकेरलान)}

sea contact with ancient Greek people (Pugazhendhi 2020c).

${ }^{4}$ One myth influence on the other myth is called influence. Without the influence of one another the resemblances seems between two myths and it is merely coincidence is called Parallels. 
though originate separately; at the end get connected. The myth of Rama seems to be a combination of the myths of Iole and Deianira. The resemblances can be categorised under several heads.

\section{Archery and Receiving Celestial Arms}

There are numerous developments in the history of war weapons. Stones and bones were first stage, metal sword were the second stage. The sword can attack the enemy nearby. The third stage in the development of the war weapon was the invention of bow and arrow. It can attack even enemies far off. The development of war weapons such as archery is reflected in the myths of Herakles. Herakles is depicted with a weapon, club in general. In this myth Herakles learned the art of archery and then received many celestial arms.

Having first learned from Eurytus the art of archery, Hercules received a sword from Hermes, a bow and arrows from Apollo, a golden breastplate from Hephaestus, and a robe from Athena; for he had himself cut a club at Nemea.

Apollod. 2.4.11

Apollodorus, Library and Epitome (George Frazer 1921)

Thus this myth mentions about the art of learning archery from Eurytus followed by receiving varied arms. This myth also relates Herakles with Eurytus and does not clarify the age of the Herakles. Learning archery and receiving varied arms are also seen in the myth of Rama.

"Ráma, the world's dear paragon.

He best the elephant could guide.

Urge the fleet car, the charger ride;

A master he of bowman's skill" (Canto XIX: The Birth of the Princes, Book I, Rámáyan of Válmíki) (Ralph 1874).

In the myth of Rama, Rama learned archery at his very young age. Then he received celestial arms.

"Accept this mighty bow, divine.

Whereon red gold and diamonds shine;

"Twas by the Heavenly Artist planned" (Canto XII: The Heavenly Bow. Book III, Rámáyan of Válmíki) (Ralph 1874).

Thus in both the myths, there are similarities of learning archery followed by receiving arms. When archery was invented, the skill of using the same was portrayed as a mark of bravery, since it plays a vital role in winning the enemies all around.

On the contrary, archery was also looked as an act of cowardness in that era.

"[160] who never buckled shield to arm nor faced the spear, but with a bow, that coward's weapon, was ever ready to run away. Archery is no test of manly bravery; 
no! he is a man who keeps his post in the ranks and steadily faces the swift wound the spear may plough [165]" (Heracles, Euripides) (Coleridge 1938).

Similarly, when Rama used his archery he was blamed for his cowardness to use the same to fight against enemies.

"The wounded Báli, when he saw

Ráma and Lakshman nearer draw.

Keen words to Raghu's son, impressed

With justice' holy stamp, addressed:

'What fame, from one thou hast not slain

In front of battle, canst thou gain,

Whose secret hand has laid me low

When madly fighting with my foe?" (Canto XVII, Báli’s Speech, Book IV, Rámáyan of Válmíki) (Ralph 1874).

Though philosophically, archery was considered as coward's weapon, it was also looked upon as a symbol of bravery. So, in those days brides choose life partner who mastered archery.

\section{Archery Competition and Marriage}

After learning archery, Herakles participated in an archery competition that was conducted to choose a life partner for Iole.

After his labours Hercules went to Thebes and gave Megara to Iolaus, and, wishing himself to wed, he ascertained that Eurytus, prince of Oechalia, had proposed the hand of his daughter Iole as a prize to him who should vanquish himself and his sons in archery. So he came to Oechalia, and though he proved himself better than them at archery, yet he did not get the bride; for while Iphitus, the elder of Eurytus's sons, said that Iole should be given to Hercules, Eurytus and the others refused, and said they feared that, if he got children, he would again kill his offspring.

(Apollod. 2.6.1) (George Frazer 1921).

Finally, Herakles won the archery competition. This myth is also related to Eurytus who was the father of Iole. Though Herakles won the competition, Eurytus refused to have his daughter marry Herakles. This situation is discussed in this myth. Similarly, a king participated in the archery competition to win the heart of the bride is also seen in Rama.

\section{Rama}

In the myth of Rama, the man who could operate the big bow shall marry Princess Sita. The Prince of different countries participated in this competition failed in their attempt. Rama participated in the competition and got victory.

"Then Raghu's son, as if in sport,

Before the thousands of the court,

The weapon by the middle raised 
That all the crowd in wonder gazed.

With steady arm the string he drew

Till burst the mighty bow in two" (Canto LXVII: The Breaking of the Bow, Book I,

Rámáyan of Válmíki) (Ralph 1874).

The father of the bride agreed to have his daughter marry to the winner.

"My child, to royal Ráma wed,

New glory on our line will shed:

And true my promise will remain" (Canto LXVII: The Breaking of the Bow, Book I, Rámáyan of Válmíki) (Ralph 1874).

Instances such as attaining excellence in the art archery, winning the heart of the princess and getting married resemble in both the myths. The above thoughts are figuratively compared in Figure 2.

Figure 2. Competition and Marriage
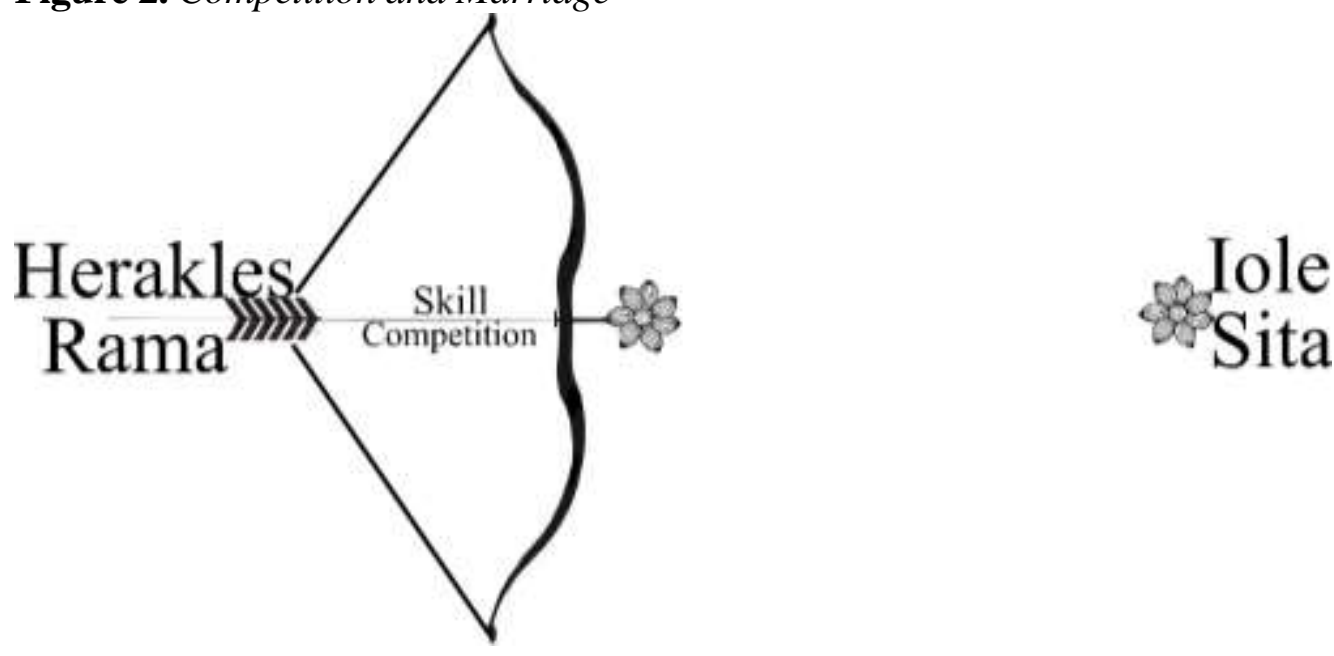

This clearly shows that both the myths belonged to the era of archery. In both the myth the archery competition determines the life partner. At this point of the myth there seems to be a main difference between them. Even though Herakles emerged victorious, Eurytus did not keep up his word and refused to give his daughter to Herakles as a prize, whereas in the myth of Rama, the father of the bride accepted to give her daughter as a prize for the winner in the archery competition. This difference shows a variation between these two myths. In the myth of Herakles, another woman Deianira also appeared. In the myth of Rama, even after marriage, Sita continues throughout the myth. The myth of Sita split itselp into two namely Iole and Deianira in the Herakles myth.

\section{Unintentional Killing of a Boy with Water}

In the myth of Herakles related to Deianira, the incidence of unintentional killing of a boy has an important place. 
Three years after his marriage to Deïaneira Heracles was dining in the home of Oeneus and Eurynomus, and the son of Architeles, who was still lad in years, was serving him, and when the boy made some slip in the service Heracles gave him a blow with his fist, and striking him too hard he unintentionally killed the lad.

(Diod. 4.36.2, Bibliotheca Historica) (Bekker 1890)

In this myth, Herakles showed his anger by slapping the boy who served the water to him. This action of Herakles led to the death of the boy. This unintentional killing of boy is also present in the myth of Rama. Here it was the father of Rama who killed the boy. In this myth the father of Rama, well versed in archery, attack the enemies through the sound produced by them.

"Kaus'alyá, In My Youthful Prime

Armed With My Bow I Wrought The Crime,

Proud Of My Skill, My Name Renowned,

An Archer Prince Who Shoots By Sound" (Canto LXIII: The Hermit's Son. Book II, Rámáyan of Válmíki) (Ralph 1874).

One day he chased an animal in the forest. He heard a sound as if a living being drinking water. He assumed the sound to be the noise of the chased animal. He immediately shot his arrow, towards that direction. Surprisingly he heard a murmuring human voice suffering with pain.

\author{
"I heard a pitcher slowly fill, \\ And thought, obscured in deepest shade, \\ An elephant the sound had made. \\ I drew a shaft that glittered bright, \\ Fell as a serpent's venomed bite; \\ I longed to lay the monster dead, \\ And to the mark my arrow sped. \\ Then in the calm of morning, clear \\ A hermit's wailing smote my ear: \\ 'Ah me, ah me,' he cried, and sank, \\ Pierced by my arrow, on the bank. \\ E'en as the weapon smote his side, \\ I heard a human voice that cried" (Canto LXIII: The Hermit's Son. Book II, \\ Rámáyan of Válmíki) (Ralph 1874).
}

Thus the father of Rama mistakenly killed a boy, who fetched water in the pond, assuming it to be a wild animal. Here it is important to know about the boy. Thus a water fetching boy was mistakenly killed by Rama's father in the myth of Rama, whereas, in the myth of Herakles he himself mistakenly killed the boy who slipped in serving water to him. Both these myths have the incident of mistakenly killing a boy with water. The action of Rama's father represents the era of archery.

\title{
Fate and Exile
}

After this incident Herakles exiled himself has a penalty for his wrong deed. 
Seeing that it was an accident, the lad's father pardoned Hercules; but Hercules wished, in accordance with the law, to suffer the penalty of exile, and resolved to depart to Ceyx at Trachis. And taking Deianira with him, he came to the river Evenus,

Apollod. 2.7

Apollodorus, The Library (George Frazer 1921).

In the myth of Herakles, it is stated that 'accordance with the law to suffer the penalty of the exile'. This statement did not clearly explain about the law in detail.

Myth of Rama

Myth of Rama describes a boy who was mistakenly killed.

"And distant, therefore, is the time

When thou shalt suffer for the crime.

The hour shall come when, crushed by woes

Like these I feel, thy life shall close:

A debt to pay in after days

Like his the priestly fee who pays.

This curse on me the hermit laid,

Nor yet his tears and groans were stayed" (Canto LXIV: Dasaratha's Death. Book II, Rámáyan of Válmíki) (Ralph 1874).

According to the reference, the curse of the fate was clearly described in the myth of Rama. Also, the duration of exile is clearly explained.

"Of him I claim the ancient debt,

That Bharat on the throne be set,

And thou, O Ráma, go this day

To Dandak forest far away.

Till nine long years and five shall end" (Canto XVIII: The Sentence. Book II, Rámáyan of Válmíki) (Ralph 1874).

The above situation is figuratively compared in Figure 3.

The context of mistaken killing, followed by the power of curse and its duration are minutely detailed in the myth of Rama, but the same are not found in the myth of Herakles. 
Figure 3. Death and Exile

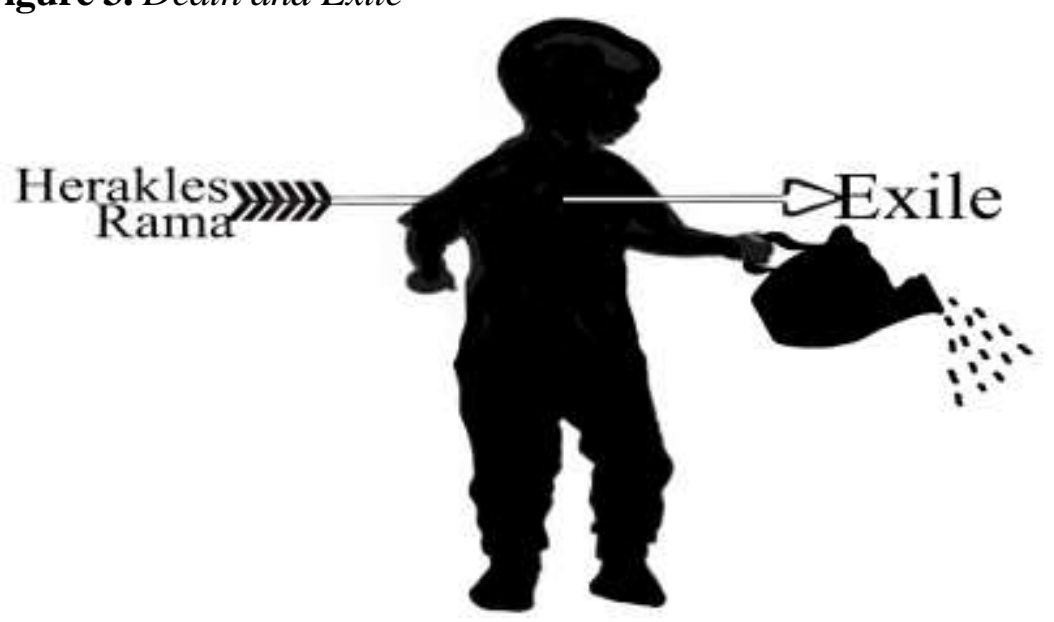

Exile and the Number of Persons

Herakles took an exile as a penalty for mistakenly killing an innocent boy who served him water. He did not undertake the exile all alone.

Overcome with grief at this misfortune he went again into voluntary exile from Calydonia along with his wife Deïaneira and Hyllus, his son by her, who was still a boy in years. And when in his journeying he arrived at the Euenus River he found there the Centaur Nessus who was conveying travellers across the river for a fee.

(Diod. 4.36.3, Bibliotheca Historica) (Bekker 1890).

His wife Deianira and his son Hyllus accompany Herakles on his exile. Thus the exile of these three resembles the myth of Rama.

"The hero ceased: and Lakshman led

Obedient to the words he said:

And Sítá followed him, and then

Came Raghu's pride, the lord of men.

With Sítá walking o'er the sand

They sought the forest, bow in hand" (Canto LII: The Crossing of Gangá. Book II, Rámáyan of Válmíki) (Ralph 1874).

In the myth of Rama, Rama along with his wife Sita and brother Lakshman exiled. In another myth Sita is mentioned as the sister of Rama.

"Once upon a time, at Benares, a great king named Dasaratha renounced the ways of evil, and reigned in righteousness. Of his sixteen thousand wives, the eldest and queen-consort bore him two sons and a daughter; the elder son was named Ramapaṇitita, or Rama the Wise, the second was named Prince Lakkhana, or Lucky, and the daughter's name was the Lady Sìtā".

No. 461, Dasaratha-Jātaka

The Jataka (Rouse 1901). 
Hence there are two variations in the myths - both Sita as wife and sister. The son who is mentioned in the myth of Herakles is mentioned as brother in the myth of Rama. Besides these differences in the relationship among the three who went on exile, the count of persons remain the same in both the myths.

\section{Crossing the River}

The main incident in the exile is crossing the river.

at which the centaur Nessus sat and ferried passengers across for hire, alleging that he had received the ferry from the gods for his righteousness. So Hercules crossed the river by himself, but on being asked to pay the fare he entrusted Deianira to Nessus to carry over.

Apollod. 2.7

Apollodorus, The Library (George Frazer 1921).

While crossing the river, Herakles is left his wife alone.

Myth of Rama

"With reverence thus to Ráma cried:

The boat is ready by the shore:

How, tell me, can I aid thee more?

$\mathrm{O}$ lord of men, it waits for thee

To cross the flood that seeks the sea,

$O$ godlike keeper of thy vow,

Embark: the boat is ready now" (Canto LII: The Crossing of Gangá. Book II, Rámáyan of Válmíki) (Ralph 1874).

In the myth of Rama, husband and the wife were not separated while crossing the river, but the separation happened at the later point of time. Hence, the separation of husband and wife is seen in both the myths.

\section{Attempt of Harassment}

Herakles took the help of a ferry man Nessus to cross the river along with his wife. When Herakles was on the other bank of the river the ferry man made an attempt to harass the wife of Herakles.

But he, in ferrying her across, attempted to violate her. She cried out, Hercules heard her, and shot Nessus to the heart when he emerged from the river.

(Apollod. 2.7., The Library) (George Frazer 1921).

Nessus carried Deïaneira across first, and becoming enamored of her, because of her beauty he tried to assault her. But when she called to her husband for help Heracles shot the Centaur with an arrow, and Nessus, struck even while he was having intercourse with her and because of the sharpness of the blow being at once on the point of death, told Deïaneira that he would give her a love-charm to the end that Heracles should never desire to approach any other woman.

(Diod. 4.36.4., Bibliotheca Historica) (George Frazer 1921). 
In a similar way in the myth of Rama his wife Sita was harassed by a sea monster.

"Rávan urged the lady meet

For love, whose words were soft and sweet.

Near and more near the giant pressed

As love's hot fire inflamed his breast.

The leader of the giant crew

His arm around the lady threw:

Thus Budha 1 with ill-omened might

Steals Rohini's delicious light.

One hand her glorious tresses grasped,

One with its ruthless pressure clasped" (Canto XLIX: The Rape of Sitá. Book III, Rámáyan of Válmíki) (Ralph 1874).

Thus Deïaneira, the wife of Herakles and Sita, the wife of Rama both underwent harassment. This harassment occurred while crossing the river in the myth of Herakles and after crossing the river in the myth of Rama.

\section{Love Charm}

Love charm is a lotion mentioned in the myth of Herakles. Herakles killed Nessus who tried to misbehave with his wife. At the time of the death Nessus gave this lotion to the wife of Herakles. Love charm is a lotion made of a special type of seed mixed with blood of Nessus. The use of the love charm is also mentioned.

Being at the point of death, Nessus called Deianira to him and said that if she would have a love charm to operate on Hercules she should mix the seed he had dropped on the ground with the blood that flowed from the wound inflicted by the barb. She did so and kept it by her.

(Apollod. 2.7., The Library) (George Frazer 1921).

This love charm makes to fall in love with the opposite - gender. On hearing that Herakles is in love with Iole, his wife Deïaneira used the love charm to make him be with her always.

At Cenaeon Heracles, wishing to perform a sacrifice, dispatched his attendant Lichas to Deïaneira his wife, commanding him to ask her for the shirt and robe which he customarily wore in the celebration of sacrifices. But when Deïaneira learned from Lichas of the love which Heracles had for Iolê, she wished him to have a greater affection for herself and so anointed the shirt with the love-charm which had been given her by the Centaur, whose intention was to bring about the death of Heracles. (Diod. 4.38.1., Bibliotheca Historica) (Bekker 1890).

Thus Deïaneira anointed the love charm on a shirt and gave to Herakles through the messenger to attract her husband towards her. The success of this effort will be discussed at the end of the article. Here it is to be noted that this idea of using love charm to attract the opposite sex is not present in the myth of Rama. 
Ring

A ring is an ornament mentioned in the myth of Herakles.

Take him the seal stamped on this signet ring

as token - he will quickly recognize it.

615, Sophocles, Trachiniae (Jebb 1892).

Here the ring is used for the purpose of identification. This ring was sent by Deïaneira to her husband Herakles through the messenger. The same is seen in the myth of Rama.

"He gave the ring that bore his name,

A token for the captive dame,

That the sad lady in her woe

The missive of her lord might know.

'This ring', he said, my wife will see,

Nor fear an envoy sent by me" (Canto XLIV: The Ring. Book IV, Rámáyan of Válmíki) (Ralph 1874).

Sítá knows nothing about Ráma, since the time she was separated by Rávan. This ring played an important role to recollect the memories and whereabouts of Rama to Sita.

"She ceased; and from her glorious hair

She took a gem that sparkled there

A token which her husband's eyes

With eager love would recognize" (Canto XXXVIII: Sitá's Gem. Book V, Rámáyan of Válmíki) (Ralph 1874).

Thus ring played an important role of identification between life partners in both the myths. In the myth of Herakles, the wife send the ring to her husband whereas in the myth of Rama, husband send the ring to wife in return, Sita send back the gem to the husband. More over the ring is also used to communicate the present state of mind along with identification of a person forgotten.

\section{Sea War for Iole}

Herakles won the archery competition to marry Iole. After winning the competition, Iole's father refused to give his daughter to Herakles. So Herakles took a war against Iole's father.

I will no longer hide the truth from you: everything is as this man has declared. A dreadful craving for the girl came over Heracles; and for her sake he destroyed and sacked Oechalia, her father's city. $\mathrm{He}$, in all fairness to him, never told me 
480 to hide these facts from you, never denied them;

Sophocles, Trachiniae (Jebb 1892).

It was mentioned that this war was related with sea.

750 After he plundered Eurytus's city he carried off the choicest spoils of battle; and, by a wave-washed headland of Euboea, Sophocles, Trachiniae (Jebb 1892).

Thus in the myth of Herakles a war took place for a woman and it was related with sea. Similar incidents are also seen in the myth of Rama.

\section{Myth of Rama}

Sita, the wife of Rama was abducted by the enemy Ravana. Rama sent the envoys in all directions in search of his wife. Then one of the envoys found the wife of Rama in a place surrounded by sea.

"Then why should Ráma's hand be slow

To free his consort from her woe?

Why spare to burn, in search of me,

The land encircled by the sea?" (Canto XXXVI: Ráma’s Ring. Book V, Rámáyan of Válmíki) (Ralph 1874).

Thus in the myth of Rama the sea war plays an important role in relieving Sita from the enemy. Here it is to be noted that both Iole, in the myth of Herakles and Sita, in the myth of Rama were supposed to marry the champion in the archery competition. This lead to the sea war for the sake of achieving the goal of attaining the woman. From the above there are instances of similarities could be seen present in both the myths.

\section{Time Duration and Sea War}

The sea war is mentioned in the myth of Herakles. Because of sea war Herakles got separated from his wife for twelve months.

He was gone far away from our city

at sea, while we waited for him

649 twelve long months, and heard nothing.

Sophocles, Trachiniae (Jebb 1892).

In the myth of Rama, Rama got separated from his wife Sita that led to the sea war. It was said that ten months have gone by since Sita's separation.

"Go, bid him speed to smite his foes

Before the year shall reach its close. 
Ten months are fled but two remain" (Canto XXXVII: Sítás Speech, Book V, Rámáyan of Válmíki) (Ralph 1874).

Further it can be observed that there is a close resemblance between the myths in terms of time duration.

\section{Sea War with a Foreign Army}

Herakles conducted a sea war against Eurytus with the help of foreign army.

When he had purged himself

he raised a foreign army and advanced

260 on Eurytus's city,

Sophocles, Trachiniae (Jebb 1892).

There is no mention about his own army. In the same way in the myth of Rama, Rama did not possess an army for his own, he sought the help of a foreign army.

\section{Foreign Army of Rama}

Rama left everything such as his country, army and kingdom to lead a life in exile. During his exile his wife Sita was abducted by a strong king. So, Rama needed a strong army to fight against the enemy. For this, Rama made an agreement with the king named Sugríva. The army of Sugríva was called 'Vánar'. With the help of this Vánar army, Rama searched his wife.

"Sugríva will his succours bring,

And all our Vánar hosts combined

Will trace the dame you long to find"' (Canto IV: Lakshman's Reply. Book IV, Rámáyan of Válmíki) (Ralph 1874).

In Tamil 'van' means 'sky'. The monkeys are called as vanar because they live on tall trees that touch skies. Here, the army of the Sugríva is described as the army of monkeys.

Army of Monkeys

Even today fishes like dolphin, birds like eagle are used in the army for the sake of locating and spying enemies. In this way Sugríva might have trained monkeys for war. Also it is possible to understand the army of monkeys in a metaphorical sense.

\section{Role of Monkey in the Myth of Rama}

The wife of Rama was cheated by a water related monster who abducted her. In order to indicate her route Sita thought of a plan and dropped her jewels along the way. 


\begin{abstract}
"He gave
me many splendid precious jewels that awed me.

When my large family saw that, they took the finger

ornaments and put them on their ears, put the ear jewels

on their fingers, those meant for the waist on their

necks, and those meant for the necks on their waists.

They were like a huge family of monkeys with gaping red

mouths scooping up the beautiful ornaments that fell to

the ground, when the mighty demon snatched away enraged

Raman's wife Seethai" (Puranānūru 378, Poet Oonpothi Pasunkudaiyār, Sanga Ilakkiam) (Tamil Virtual University 1995).
\end{abstract}

Sita did this with the belief that it would help someone to trace the route and understand her whereabouts. The wandered monkeys found the jewels and played with them.

"With earring, necklet, chain, and gem,

Descending in the midst of them:

'For these, 'she thought, 'my path may show,

And tell my lord the way I go.'

Nor did the fiend, in wild alarm,

Mark when she drew from neck and arm

And foot the gems and gold, and sent

To earth each gleaming ornament" (Canto LIV: Lanká. Book III, Rámáyan of Válmíki) (Ralph 1874).

These ornaments of Sita given to Rama provided him a better understanding of Sita's plight. In a metaphoric sense, this indicates that the monkeys have found the hidden place of Sita. The above events suggest the possibility of depicting the monkeys as metaphorized or trained one. In both the myths foreign armies are used in the war. The above thoughts are figuratively compared in Figure 4.

Figure 4. Army

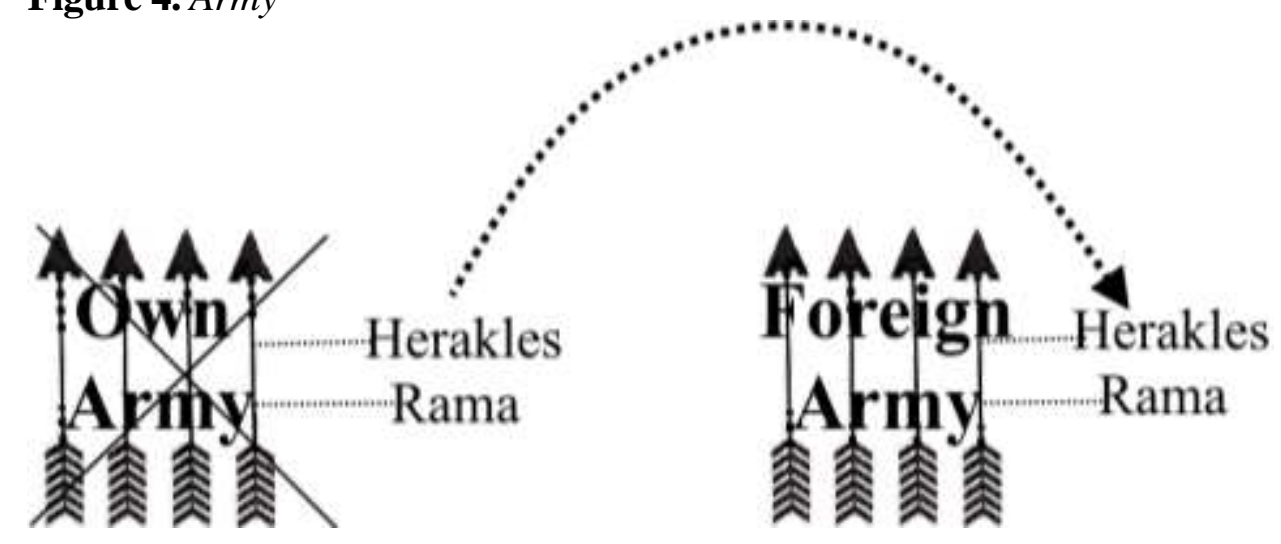

Victory over the Lady

In the myth of Herakles, with the help of a foreign army, Herakles emerged victorious by freeing a woman in the sea war. 
Messenger

Why, I heard this man say - and there were many

witnesses there - that for the girl's sake only

did Heracles slay Eurytus and conquer

Oechalia's high towers. Love alone,

Sophocles, Trachiniae (Jebb 1892).

By this, Herakles won the heart of lady Iole.

\section{Myth of Rama}

In the myth of Rama, in order to rescue his wife safely, Rama raised a foreign army and conducted a sea war. He emerged victorious and got united with his wife.

"He looked upon that archer chief

Whose full eye mocked the lotus leaf,

Arid thus the noble Vánar spake:

Now meet the queen for whose dear sake

Thy mighty task was first begun,

And now the glorious fruit is won" (Canto CXVI: The Meeting. Book VI, Rámáyan of Válmíki) (Ralph 1874).

As an outcome of the war, Rama got united with his wife Sita, were as Herakles got back his lover.

\section{Second Wife}

In the myth of Herakles, he captured lady Iole, his second wife.

Messenger

Well, when Heracles could not persuade him whose seed produced the child [360] to give him the girl for his secret concubine, he devised some petty complaint as a pretext, and made war upon her fatherland, in which, as the herald said, that Eurytus ruled. He killed the king, her father, and [365] sacked her city.

Sophocles, Trachiniae (Jebb 1892).

The above action is the main plot in the myth of Herakles. Later in the same myth, lady Iole became the wife of Herakles's son Hyllus.

Heracles

You know the daughter of king Eurytus?

Hyllus

1220 Iole? Do I understand your meaning?

Heracles

Yes, child. This is the charge I lay upon you:

if you revere my memory when I

have died, remembering the oath you swore, 
make her your wife,

Sophocles, Trachiniae (Jebb 1892).

There are two different plots with reference to second wife in the myth of Rama. In the main plot, in the myth of Rama, Ravana tried to make Sita his second wife. Therefore, Rama waged a war and won him. In the sub plot of the same myth, Báli, the brother of Sugríva, had Sugríva's wife as his second wife. Rama and Sugriva exchanged a mutual support to eachother. The former supported the later to rescue Sugríva's wife. On the other hand Sugriva extend his army to Rama for rescuing Sita, as a mark of his gratitude.

"By Báli’s conquering might oppressed,

Of power and kingship dispossessed,

Loaded with taunts of scorn and hate

I (Sugríva) left my realm and royal state.

He tore away my consort: she

Was dearer than my life to me" (Canto VIII: Ráma's Promise. Book IV, Rámáyan of Válmíki) (Ralph 1874).

\section{Second Wife and Blood Relationship}

In the myth of Herakles, the second wife Herakles became the wife of his son. This comes under blood relationship. The acceptability of Iole becoming the wife of Herakles's son is questionable. A similar relationship is also questioned in the play Hippolytus or Hippolytos by Euripides in 480 BC.

In the myth of Rama, Báli's second wife is the wife of his brother. This aspect of blood relationship is seen in Herakles.

"Thou, Báli, in thy brother's life

Hast robbed him of his wedded wife,

And keepest, scorning ancient right,

His Rumá for thine own delight.

Thy son's own wife should scarcely be

More sacred in thine eyes than she.

All duty thou hast scorned, and hence

Comes punishment for dire offence" (Canto XVIII: Ráma's Reply. Book IV, Rámáyan of Válmíki) (Ralph 1874).

In both the myths, events related with the same women who being announced as prizes for the winner in the archery competition, becomes second wife. The sea war occurred for the sake of releasing them from enemies. In both these myths the second wife happened within the same blood relationship.

\section{Suspicion on Love Sharing}

Herakles won the country of Eurytus and made Iole as a second wife. The first wife of Herakles, Deianeira was worried in sharing her love with Herakles along with Iole. 
Deianeira

540 under one blanket; this is the reward

Heracles, whom we call the good and faithful,

has given me for waiting all this time!

Sophocles, Trachiniae (Jebb 1892).

This type of relationship is also seen in the myth of Rama.

\section{Myth of Rama}

Rama won the country of Ravana for rescuing his wife. After saving his wife Sita from the enemy, Rama doubts her chastity. Sita told that she is faultless.

"If, when the giant seized his prey,

Within his hated arms I lay,

And felt the grasp I dreaded, blame

Fate and the robber, not thy dame.

What could a helpless woman do?

My heart was mine and still was true" (Canto CXVIII: Sítá's Reply. Book VI, Rámáyan of Válmíki) (Ralph 1874).

"How should my home receive again

A mistress soiled with deathless stain?

How should I brook the foul disgrace,

Scorned by my friends and all my race?

For Rávan bore thee through the sky,

And fixed on thine his evil eye.

About thy waist his arms he threw,

Close to his breast his captive drew,

And kept thee, vassal of his power,

An inmate of his ladies' bower" (Canto CXVII: Sítá's Disgrace. Book VI, Rámáyan of Válmíki) (Ralph 1874).

Rama did not accept Sita as his wife again.

The world is all before thee: flee:

Go where thou wilt, but not with me" (Canto CXVII: Sítá's Disgrace. Book VI, Rámáyan of Válmíki) (Ralph 1874).

For glory, honour and goodness, Rama rescued his wife from the enemy, but did not live with her, doubting her chastity.

Thus both the myths deal with husband and wife relationship. In the myth of Herakles, wife suspects the husband and in the myth of Rama, husband suspects the wife. 
Pyre

A fire bed is called as pyre. In the myth of Herakles, at one point of time, he asked to prepare a pyre for him.

Heracles

And will you build the pyre, as I have told you?

1213, Sophocles, Trachiniae (Jebb 1892). Rama.

This happened because of his love sharing. The same is seen in the myth of

Pyre in the Myth of Rama

Rama won the country by defeating his enemy Ravana and liberated his wife Sita. In the myth of Herakles, the two women Iole and Deianira were related with Herakles. His wife Deianira alleged Herakles on sharing of love with Iole. In the myth of Rama, it is only one woman. Hence there is no allegation against Rama. Since the wife of Rama was under the custody of Ravana, his enemy, Rama doubted her chastity. Sita in order to prove her chastity requested to build a pyre.

"To Lakshman then she turned and spoke

While sobs and sighs her utterance broke:

Sumitrá's son, a pile prepare,

My refuge in my dark despair.

I will not live to bear this weight

Of shame, forlorn and desolate.

The kindled fire my woes shall end

And be my best and surest friend" (Canto CXVIII: Sítá's Reply. Book VI, Rámáyan of Válmíki) (Ralph 1874).

Accordingly Sita entered the pyre.

"Within the flame's wild fury passed.

Then rose a piercing cry from all

Dames, children, men, who saw her fall

Adorned with gems and gay attire

Beneath the fury of the fire" (Canto CXVIII: Sítá's Reply. Book VI, Rámáyan of Válmíki) (Ralph 1874).

Though Sita was in the custody of the enemy, she retained her chastity. The quality of chastity protected her and so she came out of the fire unharmed.

"Receive, O King, thy queen again,

Pure, ever pure from spot and stain" (Canto CXX: Sítá Restored. Book VI, Rámáyan of Válmíki) (Ralph 1874).

At the end the fire God appeared and assured the chastity of Sita. Then Rama explained that he did not have any doubt on the chastity of Sita, but she was made 
to undergo this test to prove herself chastised to the society. Thus pyre played an important role in the test for chastity related with the husband and wife relationship. The above thoughts are visualized in Figure 5.

Figure 5. War Love and Pyre
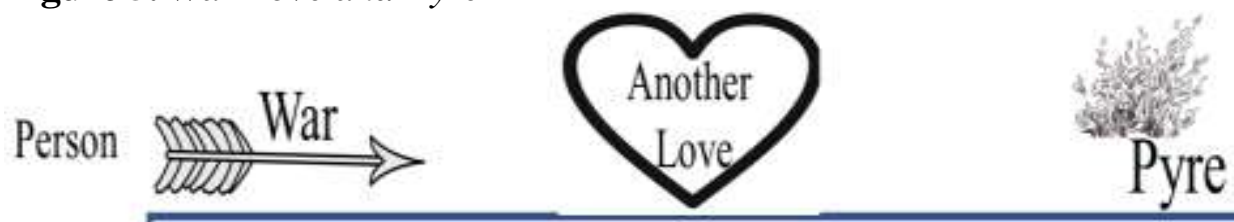

In the myth of Herakles, the doubt was on Herakles and he entered the pyre. In the myth of Rama, Sita was doubted and so she entered the pyre. The above thoughts are figuratively compared in Figure 6.

Figure 6. War Love and Pyre - Comparison
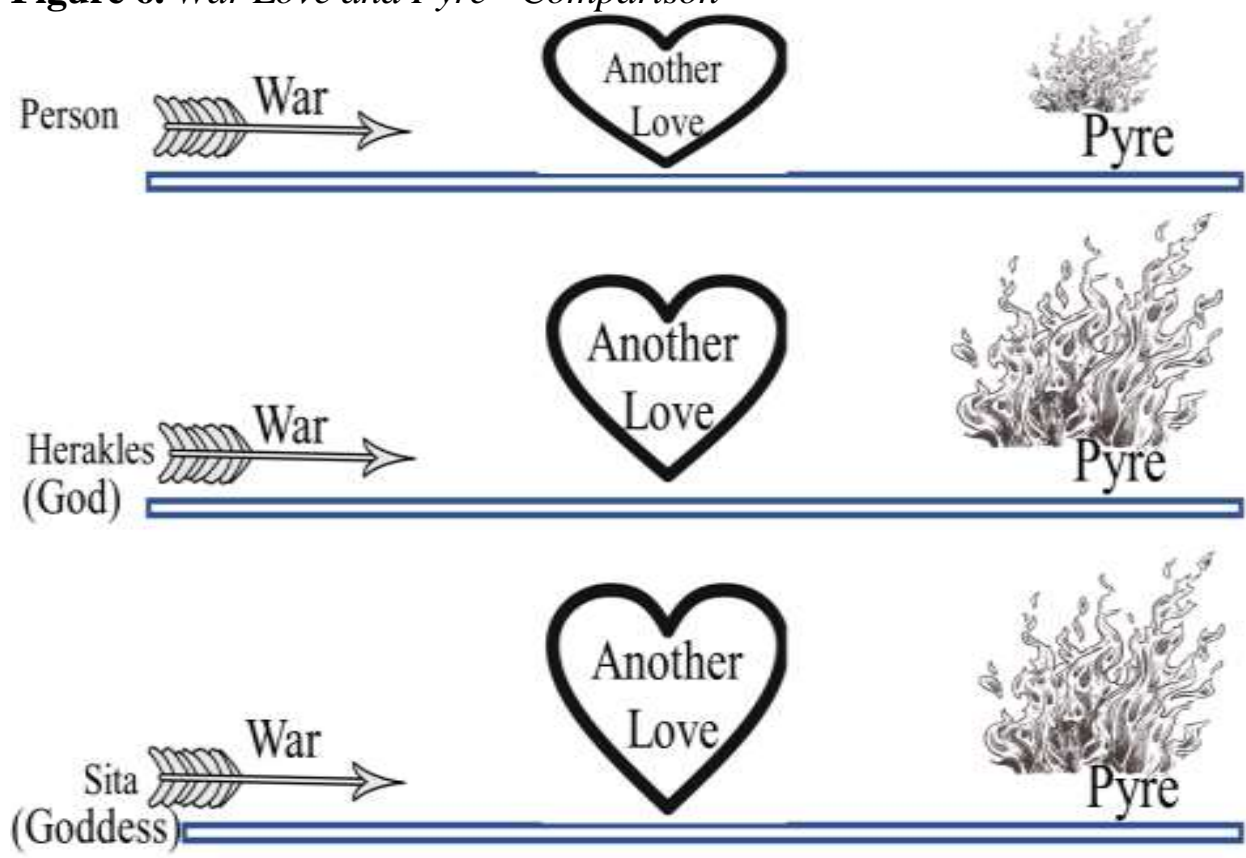

In the myth of Herakles, the concept of love charm is present. The same is absent in the myth of Rama. These variations need to be researched.

Influence of other Myths

In the myth of Herakles, the concept of love charm was used to control one of the life partners from loving the other. The same is mentioned in the Greek epic Medea.

the beast said, "Daughter of old Oeneus, listen 570 to me, and you will profit from this voyage, for I will never carry any other. 
Take in your hands the clotted blood around my wound, in which the monstrous beast of Lerna, Hydra, once dipped his arrows of black gall; and this will be a love-charm for the heart of Heracles, so that he will not ever love anyone he looks on more than you. Sophocles, Trachiniae (Jebb 1892).

[780] I shall ask that the children be allowed to stay, not with the thought that I might leave my children behind on hostile soil for my enemies to insult, but so that I may kill the princess by guile. I shall send them bearing gifts

[785] [bearing them to the bride so as not to be exiled,] a finely-woven gown and a diadem of beaten gold. If she takes this finery and puts it on, she will die a painful death, and likewise anyone who touches her: with such poisons will I smear these gifts.

Eur. Med (Kovacs 1994)

Thus the love charm present in the myth of Herakles is also present in the myth of Medea. The effect of the love charm was also same in both the myths, Herakles and Medea.

but when the gory flame began to blaze up from the offerings on the sappy pine, sweat covered all his body, and the robe clung to his sides as if glued by a craftsman to every joint; and from his very bones 770 shot up spasmodic, stinging pangs: the poison, like some detested, bloody snake's, devoured him. Then he cried out aloud for ill-starred Lichas, who was in no way guilty of your crime, to ask what treachery made him bring the robe; but he, unlucky man! knew not, and answered he had but brought the gift which you had given.

When Heracles heard this a penetrating convulsive spasm clutched his lungs, and he seized Lichas where the ankle joins the foot 780 and dashed him on a rock swept by the sea so that the white brain seeped among his hairs, and all his shattered skull was bloodied over. Sophocles, Trachiniae (Jebb 1892)

[1185] For she was being attacked with a double pain. The golden circlet about her head shot forth a terrible stream of consuming fire, and the fine-spun gown, gift of your sons, was eating into the wretched girl's white flesh. [1190]

Eur. Med (Kovacs 1994).

So the concept of love charm present in the myth of Herakles which was not in the myth of Rama, might be present due to the influence of the myth of Medea. In the same way the woman entering the pyre in the myth of Rama which varies 
from the myth of Herakles might be the influence of the other myths. This could be an influence of Tamil literature.

"The funeral pyre of black twigs might be fearful to you.

It is not fearful to me

who has lost my broad-shouldered husband.

A pond with thick-petaled, blooming lotus blossoms

and a fire are both same to me!" (Puranānūru 246, Queen Perunkōpendu, Sanga Ilakkiam) (Tamil Virtual University 1995).

(wife of Ollaiyūr Thantha Pāndiyan PoothaPāndiyan sang this after the death of her husband)

Here the wife of the king, entered the pyre without any fear during her husband's cremation. This is seen as a mark of affection of a wife towards the husband. This myth might have influenced the variation in the myth of Rama and the myth of Herakles.

\section{Immortality}

In the myth of Herakles, after entering the pyre Herakles attained immortality.

proceeded to Mount Oeta, in the Trachinian territory, and there constructed a pyre, mounted it, and gave orders to kindle it. When no one would do so, Poeas, passing by to look for his flocks, set a light to it. On him Hercules bestowed his bow. While the pyre was burning, it is said that a cloud passed under Hercules and with a peal of thunder wafted him up to heaven. Thereafter he obtained immortality,

Apollod. 2.

Apollodorus, The Library (George Frazer 1921).

A similar event also occurs in the myth of Rama.

\section{Immortality of Rama}

As the wife of Rama entered the fire lit pyre to prove her chastity, the fire God appeared and pestified the purity of Sita. After this incident everyone depicted Rama and Sita as God and Goddess. In the myth of Herakles, after entering the pyre, Herakles alone was considered to be a God. On the other hand in the myth of Rama though Sita alone went into the pyre and came out successfully, both Rama and Sita are seen God and Goddess.

"Couldst thou, the Lord of all, couldst thou,

Creator of the worlds, allow

Thy queen, thy spouse to brave the fire

And give her body to the pyre?

Thou Krishna of unequalled might.

Thy hand, O Lord, the hills and plains, And earth with all her life sustains; 
Thou wilt appear in serpent form

When sinks the earth in fire and storm.

Queen Sítá of the lovely brows

Is Lakshmí thy celestial spouse" (Canto CXIX: Glory to Vishnu. Book VI, Rámáyan of Válmíki) (Ralph 1874).

In the myth of Rama, male only is considered to be important. In Tamil religion there is already an existence of worship of a chastised woman. The pyre which is related to male in Greek, is connected as female in Indian myth. Hence the female portrayed as Goddess. These Gods and Goddesses find a place in Buddhism.

"The Master having ended this discourse, declared the Truths, and identified the Birth: (now at the conclusion of the Truths, the land-owner was established in the fruit of the First Path:) "At that time the king Suddhodana was king Dasaratha, Mahāmāyā was the mother, Rāhulā's mother was Sìtā, Ānanda was Bharata, and I (Buddha) myself was Rāma-paṇ̣ita"" (No. 461, Dasaratha-Jātaka, Jataka (Buddha’s former birth) (Rouse 1901).

Thus Rama entered Buddhism. The myth of Herakles, though initially seen as two different myths, later became a single myth. The myth of Rama starts and ends with only one woman. The variations of the myths are compared in Figure 7.

Figure 7. Variation
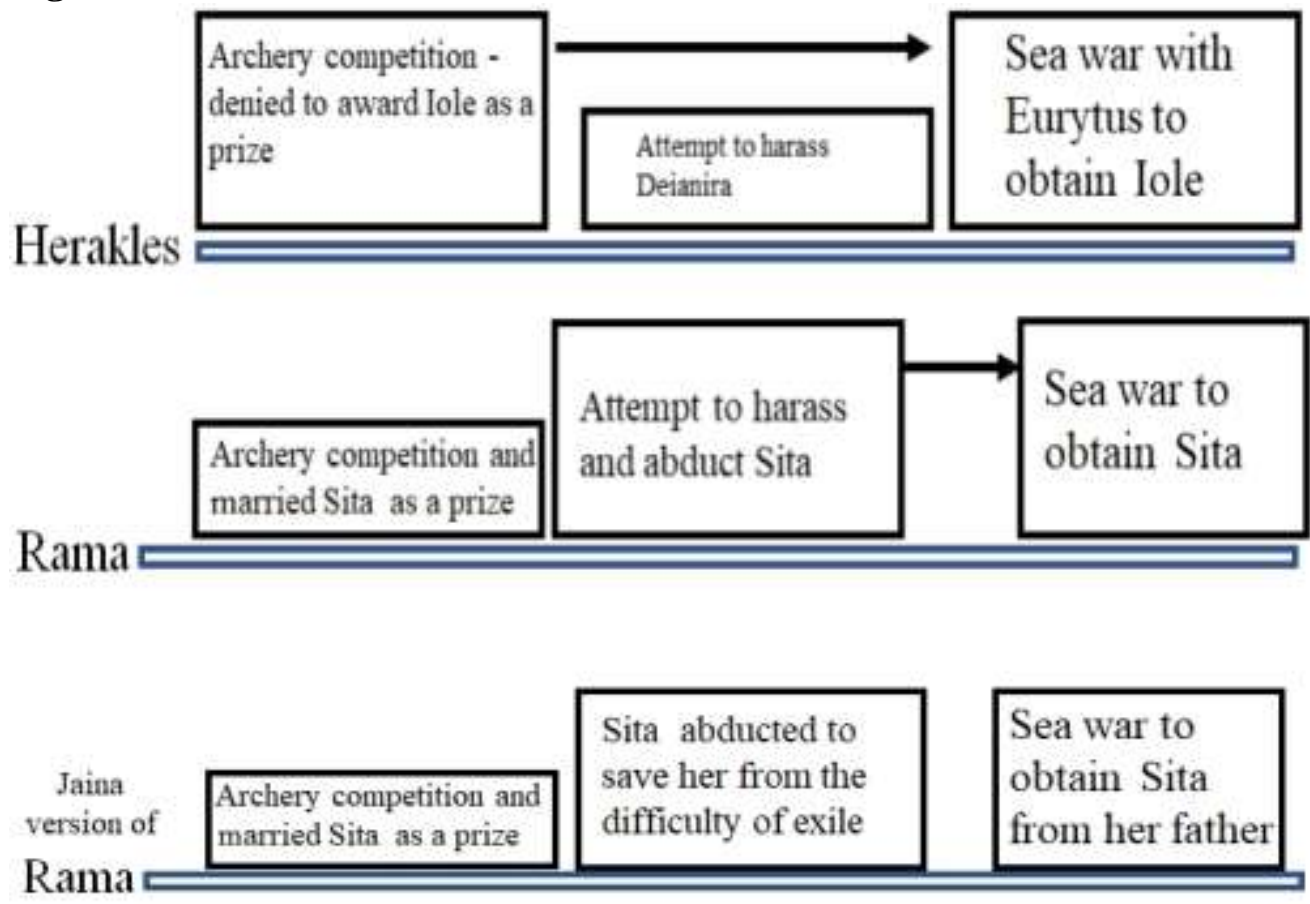

According to the Jaina version of Ramayana, Sita was born as the daughter of Ravana. However the astrologers predicted that the first child of Ravana would 
destroy his lineage. Therefore Ravana ordered his servants to take his child to some distant place and bury her. Hence, that child was found and adopted by Janaka. In Sanghadasa's Jaina version of Ramayana, and also in Adbhuta Ramayana, Sita titled Vasudevahindi born as the daughter of Ravana. According to this version, astrologers predict that first child of Vidyadhara Maya (Ravana's wife) will destroy his lineage.

On comparison, these two myths have more resemblances than dissimilarities. All the above said aspects are presented in Table 1.

Table 1. Comparison of Myths

\begin{tabular}{|c|c|c|c|}
\hline & Herakles and Iole & Rama and Sita & variation \\
\hline 1. & Learned archery for first time & Learned archery for first time & \\
\hline 2. & Received celestial arms & Received celestial arms & \\
\hline 3. & $\begin{array}{c}\text { Took part in archery } \\
\text { competition with an } \\
\text { expectation to win over Iole as } \\
\text { prize }\end{array}$ & $\begin{array}{c}\text { Took part in archery } \\
\text { competition with an } \\
\text { expectation to win over Sita as } \\
\text { prize }\end{array}$ & \\
\hline 4. & $\begin{array}{l}\text { Herakles won the archery } \\
\text { competition }\end{array}$ & $\begin{array}{l}\text { Rama won the archery } \\
\text { competition }\end{array}$ & \\
\hline 5. & $\begin{array}{l}\text { Eurytus refused to grant the } \\
\text { competition prize }\end{array}$ & & $\begin{array}{l}\text { Rama won Sita as prize } \\
\text { and married her }\end{array}$ \\
\hline 6. & $\begin{array}{l}\text { Herakles unintentionally } \\
\text { killed the boy who was } \\
\text { pouring water }\end{array}$ & $\begin{array}{c}\text { Rama's father unintentionally } \\
\text { killed the boy who was } \\
\text { pouring water }\end{array}$ & $\begin{array}{l}\text { 1. The mistake of the } \\
\text { father impacted the life } \\
\text { of Rama } \\
\text { 2. The mistake made by } \\
\text { Herakles affects his own } \\
\text { life }\end{array}$ \\
\hline 7. & $\begin{array}{l}\text { Unintentional act of killing } \\
\text { was forgiven } \\
\end{array}$ & & Not forgiven and cursed \\
\hline 8. & Exile voluntary & Curse and exile & \\
\hline 9. & $\begin{array}{l}\text { Exile with two persons - wife } \\
\text { and son }\end{array}$ & $\begin{array}{l}\text { Exile with two persons - } \\
\text { 1. Brother and Wife } \\
\text { 2. Brother and Sister } \\
\end{array}$ & \\
\hline 10. & Crossing the river & Crossing the river & \\
\hline 11. & $\begin{array}{l}\text { The river water separated } \\
\text { husband and wife }\end{array}$ & $\begin{array}{l}\text { The water separated husband } \\
\text { and wife }\end{array}$ & $\begin{array}{l}\text { 1. River and sea water } \\
\text { separated the life of } \\
\text { Herakles } \\
\text { 2. Sea water separated } \\
\text { the life of Rama }\end{array}$ \\
\hline 12. & $\begin{array}{l}\text { The person related with water } \\
\text { attempted to misbehave with } \\
\text { woman }\end{array}$ & $\begin{array}{l}\text { The person related with water } \\
\text { attempted to misbehave with } \\
\text { woman }\end{array}$ & $\begin{array}{l}\text { 1. The ferry man of the } \\
\text { river attempted to } \\
\text { misbehave with the wife } \\
\text { of Herakles } \\
\text { 2. The person who } \\
\text { belonged to other end of } \\
\text { the sea attempted to } \\
\text { misbehave with the wife } \\
\text { of Rama }\end{array}$ \\
\hline 13. & $\begin{array}{l}\text { Attempted person was a } \\
\text { monster }\end{array}$ & $\begin{array}{l}\text { Attempted person was a } \\
\text { monster }\end{array}$ & \\
\hline 14. & $\begin{array}{l}\text { Attempted person was killed } \\
\text { by the hero }\end{array}$ & $\begin{array}{l}\text { Attempted person was killed } \\
\text { by the hero }\end{array}$ & \\
\hline 15. & Killed person gave a love & & \\
\hline
\end{tabular}




\begin{tabular}{|c|c|c|c|}
\hline & charm to Deianira & & \\
\hline 16. & Sea war & Sea war & \\
\hline 17. & $\begin{array}{c}\text { Sea war happened to capture } \\
\text { Iole }\end{array}$ & & $\begin{array}{c}\text { Sea war was conducted } \\
\text { by Rama for his one and } \\
\text { only wife } \\
\end{array}$ \\
\hline 18. & $\begin{array}{c}\text { Husband and wife got } \\
\text { separated during the sea war }\end{array}$ & $\begin{array}{c}\text { Husband and wife got } \\
\text { separated during the sea war }\end{array}$ & $\begin{array}{l}\text { 1. Deianira was in a } \\
\text { separate place during the } \\
\text { war. } \\
\text { And Iole was in the } \\
\text { midst of war location. } \\
\text { 2. Sita was in the custody } \\
\text { of the enemy and in the } \\
\text { war location. }\end{array}$ \\
\hline 19. & $\begin{array}{l}\text { Herakles won the sea war and } \\
\text { got Iole }\end{array}$ & $\begin{array}{c}\text { Rama won the sea war and } \\
\text { got Sita }\end{array}$ & \\
\hline 20. & $\begin{array}{l}\text { At the end of sea war wife } \\
\text { (Deianira) suspected the } \\
\text { chastity of her husband } \\
\text { (Herakles) }\end{array}$ & & $\begin{array}{l}\text { At the end of sea war } \\
\text { Rama suspected the } \\
\text { chastity of Sita }\end{array}$ \\
\hline 21. & Love charm was used by wife & & \\
\hline 22. & $\begin{array}{l}\text { Ring was used for } \\
\text { identification }\end{array}$ & $\begin{array}{l}\text { Ring was used for } \\
\text { identification }\end{array}$ & \\
\hline 23. & $\begin{array}{l}\text { A pyre was made for the } \\
\text { suspected husband }\end{array}$ & & $\begin{array}{c}\text { A pyre was made for the } \\
\text { suspected wife }\end{array}$ \\
\hline 24. & $\begin{array}{l}\text { After the pyre bones were not } \\
\text { available }\end{array}$ & & $\begin{array}{l}\text { The pyre did not affect } \\
\text { the wife. So no bone is } \\
\text { available. }\end{array}$ \\
\hline 25. & $\begin{array}{l}\text { After the pyre the hero became } \\
\text { immortal }\end{array}$ & & $\begin{array}{l}\text { After the pyre husband } \\
\text { and wife are portrayed as } \\
\text { immortals. }\end{array}$ \\
\hline 26. & $\begin{array}{l}\text { The myth begins with fate and } \\
\text { ends with chastity }\end{array}$ & $\begin{array}{l}\text { The myth begins with fate and } \\
\text { end with chastity }\end{array}$ & \\
\hline 27. & $\begin{array}{l}\text { Main theme of the myth: A } \\
\text { man loving someone's wife or } \\
\text { other than his own will be } \\
\text { punished }\end{array}$ & $\begin{array}{l}\text { Main theme of the myth: A } \\
\text { man loving someone's wife } \\
\text { will be punished }\end{array}$ & \\
\hline 28. & $\begin{array}{l}\text { The hero is worshipped as } \\
\text { god in many parts of the } \\
\text { world }\end{array}$ & $\begin{array}{c}\text { The hero is worshipped as god } \\
\text { in Hinduism, Buddhism and } \\
\text { in South Asian countries }\end{array}$ & \\
\hline
\end{tabular}

Thus there are many resemblances seen in the myth of Herakles and Rama. The myth of Rama evolved as a great epic. So the obscure elements seen in the myth of Herakles were elaborated in the epic of Rama.

The Greek Historian mentions that the Indians portrayed the Herakles as their own. The resemblances seen between Herakles and Rama prove that both are same. The same person can be seen in Greek religion, Hinduism and Buddhism. There are many sacred places called temples for Rama in Tamil Nadu and all over India. In Thailand the Temple of the Emerald Buddha or Wat Phra Kaew has the story of Phra Rama, the hero of Ramakien, as the Thai Ramayana. Further, in Sri Lanka Kelaniya is a Buddhist Temple related to Rama. Thus the Greek Herakles is worshipped in the name of Rama in many parts of the world. 


\section{References}

Bekker I (1890) Diodorus Siculus bibliotheca historica. Leipzig.

Briggs BD (2006) Hebrew and English Lexicon, Unabridged, Biblesoft,Inc.

Coleridge EP (1938) Euripides Heracles. New York: Random House.

Eberhard ABG (1885) Indica Arrian. Leipzig.

George Frazer J (1921) Apollodorus the Library. London: William Heinemann Ltd., Cambridge: Harvard University Press.

Griffith. Ralph T.H. (1896) The Rig Veda. India: sacred-texts.com.

Jebb R (1892) Sophocles Trachiniae. Cambridge: Cambridge University Press.

Kausalya H (2018) Nālāyira divya prabhandam paśurams by Azhvārs (Four thousands sacred songs). Madurai, Tamil Nadu, India.

Kovacs D (1994) Euripides Medea. Cambridge: Harvard University Press.

NASB (1981) NAS Exhaustive Concordance of the Bible with Hebrew - Aramaic and Greek Dictionaries. The Lockman Foundation.

Padilla MW (1998) The myths of Herakles in ancient Greece. University Press of America.

Pugazhendhi D (2020a) The ancient sea trade of the Hebrews with Tamil Nadu, India with reference to the biblical word 'Thukkiyyim' [Peacock]. Global Journal of HumanSocial Science Research S.1.(Jul): 23-33.

Pugazhendhi D (2020b) The Greek root word 'Kos' and the trade of ancient Greek with Tamil Nadu, India. International Journal of Humanities and Social Sciences 14(3): 185-192.

Pugazhendhi D (2020c) Comparison between the grammar of Greek Sapphic and Tamil Seppal songs. Athens Journal of Philology 7(3): 147-170.

Ralph GTH (1874) Rámáyan of Válmíki. India: sacred-texts.com.

Rouse WHD (1901) The Jataka - Buddha's former birth. India: sacred-texts.com.

Tamil Virtual University (1995) Sangam literature. Tamil Nadu, India: Government of Tamil Nadu. 
